\title{
J H J A Greyvenstein en A S Geyser se teologiese denke oor die volkskerkgedagte
}

Ernest van Eck

Universiteit van Pretoria

Tydelik-deeltydse dosent: Departement Nuwe-Testamentiese Wetenskap (Afd A)

\begin{abstract}
The theological thoughts of J H J A Greyvenstein and A S Geyser on the concept 'people's church'

This paper - in two parts - aims to participate in the current debate regarding the writing of a new church order for the Nederduitsch Hervormde Kerk van Afrika, concentrating on Article III of the current church order. As a debate within the Nederduitsch Hervormde Kerk, the. first article traces the thoughts of two previous professors in New Testament Studies, J H J A Greyvenstein and A S Geyser, on the concept 'people's church' ('volkskerk'). In the following article Greyvenstein and Geyser's understanding of the Hervormde Kerk as 'peoples church' ('volkskerk') will critically be evaluated by means of a social-scientific analysis of meals as ceremonies in Mark's gospel.
\end{abstract}

Sonder om die tradisie van die vadere uitgesproke met goddelike gesag te beklee, redeneer die ideoloog graag dat die vaders tog nie verkeerd kon wees in hulle verstaan van die Woord nie en origens gee hy in die praktyk, so nie in beginsel nie, aan die tradisie in elk geval dieselfde geldigheid as aan die Woord.

(Geyser 1960/1961b:304)

Eintlik het die Kerk geen ander bestaansrede nie as om te getuig dat Jesus die Christus die openbaring van Gods liefde is nie .... Want die Kerk het tot enige en enigste taak om die Evangelie te verkondig tydig en ontydig, op alle plekke aan alle mense en instansies onder alle omstandighede. As hy daaraan nie voldoen nie of nie kan voldoen nie, kom die Kerk as Kerk in gedrang.

(Geyser 1951:9; 1960:18)

* Referaat gelewer op 26 Mei 1994, tydens 'n Nuwe-Testamentiese gespreksgroep-byeenkoms onder leiding van prof dr G M M Pelser, Fakulteit Teologie (Afd A), Universiteit van Pretoria. 


\section{INLEIDING}

Die Nederduitsch Hervormde Kerk van Afrika beleef tans 'n tydperk van intensiewe teologiese debatvoering oor verskeie sake. In die afgelope jaar is daar in Die Hervormer reeds debat gevoer, en word nog steeds debat gevoer, oor onder andere die volgende sake: Die kerk se etos en teologiese erfenis (Boshoff 1990:6; 1992:4; 1993:5), ortodoksisme en modernisme (Hindley 1993:5, 7; Van Wyk 1993a:4; 1993b:4; 1994a: 4; 1994b:4; 1994c:4; Loader, in De Kat 1993:75; Loader 1993:6; Van Biljon 1993:6; Wolmarans 1993:6; Jansen 1993:6; Van der Merwe 1993:6), die verhouding tussen kerk en teologie (Van Aarde 1993a:5-6; Van Wyk 1993c:4; 1993d:4; Koekemoer 1993:3, 7); die verhouding tussen kerk en belydenis (Pont 1994b:5; 1994c:5; Van Eck 1994b:4, 8), die verhouding tussen filosofie en teologie (Beukes 1994:6; Dreyer 1994:5; Van Wyk 1994a:5; 1994b:6), die metaforisiteit van die teologie (Van Aarde 1993d:5-6; 1994a:5-6; Breytenbach 1994:2) en die rol van die kerk in die derde millennium (Van Aarde 1993b:5, 7; Dreyer 1994:5; Pont 1994a:5, 8).

Oor hierdie debatvoering in die Nederduitsch Hervormde Kerk skryf die redakteur van Die Hervormer in die redaksionele kolom van die 1 September-uitgawe (1993) soos volg:

Baiekeer raak 'n mens gefrustreerd oor ons klaarblyklike onvermoë om tot volwasse en ewewigtige kerklike en teologiese debatvoering oor sake van aktuele belang te kom. Dit loop of uit op 'n politieke of teologiese verdagmakery of verkettering van mekaar, of op ' $n$ onbeheersde en onwaardige skellery op mekaar.

(Van Wyk 1993d:4)

Van Wyk (1994a:4) pleit ook in die redaksionele kolom van die 15 Januarie-uitgawe (1994) dat die predikante en teoloë van die kerk mekaar sal-hoor, mekaar se integriteit sal aanvaar en in so ' $n$ gesindheid die huidige debatvoering in die kerk wyer en dieper sal voer. In die 15 Mei-uitgawe (1994) van Die Hervormer verwys Van Wyk (1994c: 4) weer eens na die huidige debatvoering in die kerk. Hy stel dat dit aanvaar moet word dat die kerk die volgende paar jaar 'n tyd van intense teologiese debatvoering tegemoetgaan, 'n debat wat veral gaan 'kulmineer in die gesprek rondom en die werk aan 'n nuwe Kerkorde' (Van Wyk 1994c:4). Daarom pleit hy weer dat die predikante en teoloë van die kerk 'teologies koelkoppig', sonder 'bose agterdog' en 'in liefde', aan die toekomstige debat sal deelneem (Van Wyk 1994c:4).

Die onderhawige artikel wil in twee opsigte aansluit by bogenoemde oproepe van die redakteur van Die Hervormer: Eerstens wil dit deelneem aan die gesprek rondom die skryf van die nuwe Kerkorde, en tweedens op so 'n wyse dat dit uitdrukking gee aan die gees van debatvoering soos uitgedruk en versoek deur die redakteur van Die Hervormer. 
Wat die skryf van die nuwe Kerkorde betref, het dit reeds duidelik geword dat een van die sake wat deeglike aandag sal en moet ontvang, die 'saak van Artikel III' is (Botha \& Pont 1993:3). Die Nederduitsch Hervormde Kerk van Afrika het by verskeie geleenthede in die verlede daarop klem gelê het dat Artikel III niks anders as 'n praktiese reëling is nie ( $\mathrm{d}$ w s, 'n lewenskwessie en nie 'n leerkwessie nie). Tog sal in alle billikheid egter erken moet word dat Artikel III meer as net 'n praktiese reëling is, deurdat dit geslote lidmaatskap en geslote eredienste in die Hervormde Kerk reël. As volkskerk, maak Artikel III daarom die Hervormde Kerk 'n eksklusiewe volkskerk' .

Die vraag is egter: Kan 'n eksklusiewe volkskerk op Skriftuurlike gronde verdedig word? Hierdie is myns insiens die vraag waaraan die Nederduitsch Hervormde Kerk in die toekomstige debat rondom die nuwe kerkwet ernstig aandag sal moet gee.

Die onderhawige bydrae wil versigtige treë in hierdie debat gee. Omdat hierdie debat myns insiens in die eerste plek ' $n$ kerklike debat behoort te wees, word die debat ingelui met Greyvenstein en Geyser, twee van die eerste Nuwe-Testamentici van die Hervormde Kerk, se verstaan van die volkskerkgedagte. In 'n tweede artikel sal 'n kritiese evaluering van Greyvenstein en Geyser se insigte rakende die volkskerkgedagte gedoen word deur te kyk na maaltye/etes as 'seremonies' in Markus, gesien vanuit 'n sosiaal-wetenskaplike perspektief.

\section{GREYVENSTEIN SE VERSTAAN VAN DIE WESE VAN DIE KERK}

Greyvenstein het in geen gepubliseerde geskrif (kyk Van Aarde 1992a:156 vir 'n lys van Greyvenstein se belangrikste publikasies), asook in sy klasaantekeninge (kyk Venter 1917/1918/1919/1919-1920), direk verwys na die Nederduitsch Hervormde Kerk van Afrika se selfverstaan as volkskerk en die daarmee gepaardgaande Artikel II/III en sendingbeleid van die kerk nie. Die rede hiervoor is waarskynlik die feit dat in die tydperk 1917-1945 - die tydperk wat hy hoogleraar in onder andere die NuweTestamentiese Wetenskap was - die Hervormde Kerk se selfverstaan as volkskerk nie 'n omstrede saak in die kerk was nie. Uit literatuur beskikbaar (kyk bv Van Staden 1994a:715; Van Wyk 1994:772) wil dit dan ook lyk asof die debat rondom die handhawing van Artikel III eers in die begin van die sestigerjare vir die eerste keer in die Hervormde Kerk werklik sy verskyning gemaak het ${ }^{2}$. Redes vir hierdie feit sou aangevoer kon word, maar daar word nie nou daarop ingegaan nie (kyk egter Oberholzer 1993:880).

Die feit dat Greyvenstein nie oor bogenoemde sake (d w s, die begrip volkskerk, Artikel III en die kerk se sendingbeleid) geskryf het nie, beteken egter nie dat hy nie 'n bepaalde standpunt in hierdie verband gehad het nie. Inteendeel. Uit uitsprake wat Greyvenstein in onder andere oordenkings in Die Hervormer (Greyvenstein 1916:1-3; 1917:1-3; 1928:1; 1936:6-9), tydens openbare optredes (kyk o a Greyvenstein 1933:6- 
7), en in wetenskaplike publikasies (kyk o a Greyvenstein 1943/1944:3-9) gemaak het, kan dit myns insiens afgelei word dat Greyvenstein nie 'n voorstaander van 'n eksklusiewe volkskerk (wat Artikel III in wese is) was nie.

Greyvenstein se twee sterkste uitsprake teenoor eksklusiwistiese volkskerke word in 'n oordenking oor Matteus 16:18 gevind (Greyvenstein 1936:6-9), en in 'n artikel oor die gedagtewêreld van Paulus wat hy in die eerste uitgawe van die Hervormde Teologiese Studies geskryf het (Greyvenstein 1943/1944:3-9). In eersgenoemde skryf hy soos volg: In Matteus 16:18 noem Christus die skare van gelowiges 'my gemeente'. $\mathrm{Hy}$ is die Hoof van die liggaam, die liggaam is die gelowiges, en die gelowiges is gemeente van Christus wat ten nouste met mekaar moet saamlewe. Die gemeente bestaan uit almal wat van God die wedergeboorte ontvang het, mense 'uit alle geslachten en volken, een gemeenschap, waarin de liefde wil van God volkomen verwerkelikt moet worden' (Greyvenstein 1936:7).

Volgens Greyvenstein (1936:7) word in die Nuwe Testament veral die geestelike wese van die kerk beklemtoon: Die geestelike lewe, die geestelike waardes en die lewe van liefde teenoor God en die naaste, waar gelowiges, toegewyd aan God, mekaar verstaan, help en met mekaar saamwerk. Die bloei van die kerk hang daarom af van gelowiges se geestelike gemeenskap met God en die ware broederskap tussen mense. Verloor die kerk egter haar geestelike karakter, 'word zij een soort sociale, filantropiese inrichting, een inrichting voor volksverlichting of zuiwere etiese kultuur, dan houdt zij op Kerk te zijn (Greyvenstein 1936:7; my beklemtoning). Wat die kerk egter wel moet wees, en waartoe die kerk wel geroep is, is om die gewete van die wêreld te wees (Greyvenstein 1936:7). In sy artikel wat handel oor die gedagtewêreld van Paulus sê hy die volgende:

Wat sy etiese beskouinge betref gaan Paulus uit van sekere grondveronderstellinge. Ons kry die grondbeginsel van die eenheid van die menslike geslag. God 'het uit een bloed al die nasies van die mensdom gemaak om oor die hele arde te woon' Hand. 17:26 .... Al die eeue deur nog het die mensheid geweier om hierdie beginsel in al sy konsekwensies te aanvaar. Klassevooroordeel en persoonlike en nasionale meerwaardigheidsinbeelding was nog altyd die groot struikelblokke in die weg van die liefde en algemene humaniteit.

(Greyvenstein 1943/1944:6; my beklemtoning)

Die gemeente van Christus bestaan dus uit alle geslagte en volke, en is 'n geestelike gemeenskap gegrond op die grondbeginsel van die eenheid van die menslike geslag. Die beginsel waarvolgens daar in die gemeente geleef moet word is die liefde. Klassevooroordele en persoonlike/nasionale meerwaardigheid is 'n struikelblok in die weg van hierdie liefde. 
Van hierdie liefde wat daar vir mekaar in die gemeenskap van die gelowiges behoort te bestaan, skryf Greyvenstein (1916:1-3; 1917:1-3) egter ook vroeër. In die kerk is 'de liefde ... aan het sterven. Men vergeet dat het Kristendom is de godsdienst der liefde' (Greyvenstein 1916:2; my beklemtoning). En in 1917: 'Kan er hooger, heerlijker bestemming voor den Christen zijn dan om Gods medearbeider te wezen in ' $t$ herscheppen van deze gevallen wereld tot een Paradijs van Gerechtigheid, Liefde en Heiligheid?' (Greyvenstein 1917:1; my beklemtoning).

Die kerk het dus geen ander mag as die mag van die liefde nie, en na enige ander mag moet die kerk nooit nie streef nie: 'Wij (die Hervormde Kerk - EvE) hebben geen wereldsche macht, geen staatkundige heerschappij. Laat ons dat ook niet willen' (Greyvenstein 1928:1). Greyvenstein (in Greyvenstein, Engelbrecht \& Gemser 1927: 174-177) het ook gemaan teen ' $n$ te noue relasie tussen kerk en volk: Die bewaring van die godsdienstige karakter van die volk is belangrik, en die handhawing van Christelike lewensbeginsels is die waarborg vir 'n gesonde volksbestaan. Die 'tijd der Theokratie is [egter] voorbij, en deze kon alleen in een klein volk als Israel enigzins gerealiseerd worden' (Greyvenstein, Engelbrecht \& Gemser 1927:175). Die kerk kan dus wel 'n invloed op die volkslewe uitoefen, maar die volk moet nie kerk word nie. Die kerk moet eerder die gewete van die wêreld wees (Greyvenstein 1936:7), en dus ook die gewete van die volk.

\section{GEYSER SE VERSTAAN VAN DIE WESE VAN DIE KERK EN SY KRI- TIEK OP DIE VOLKSKERKIDEE}

'n Weergawe van Geyser se verstaan van die wese van die kerk, asook sy kritiek op die volkskerkgedagte van die Nederduitsch Hervormde Kerk van Afrika, kan vanuit verskillende hoeke benader word. Daar kan byvoorbeeld betoog word dat Geyser se verstaan van die wese van die kerk, en daarmee saam sy kritiek op die volkskerkgedagte, vanaf 1952 tot en met 1960 'n radikale verandering ondergaan het (kyk Geyser 1952: 98-108; 1960:12-23) ${ }^{3}$. 'n Tweede moontlikheid sou wees om te probeer aantoon dat sekere gebeurtenisse in Geyser se akademiese loopbaan - soos byvoorbeeld sy besoek aan die Universiteit van Utrecht (en sy kontak daar met Berkelbach van der Sprenkel; kyk Geyser 1953a:5), en sy daaropvolgende kontak met en belangstelling in die ekumeniese teologie (kyk Hartin 1988:4) — 'n besliste invloed uitgeoefen het op sy verstaan van die wese van die kerk en sy beoordeling van die Nederduitsch Hervormde Kerk se volkskerkidee en sendingbeleid (vgl bv Engelbrecht 1988:4-6; Van Aarde 1992b:165). 
Die oogmerk van die onderhawige bydrae is egter nie histories van aard nie. Daar word gepoog om aan te toon dat Geyser se teologiese insigte ten opsigte van die wese van die kerk, wat die gevolg was van veral sy bestudering van die Nuwe Testament, hom geen ander keuse gelaat het om soms op 'n implisiete wyse, 'maar soms ook op 'n baie eksplisiete wyse, sy kerk se verstaan van die volkskerkidee te kritiseer nie.

Dit is dan ook die invalshoek waaruit Geyser se beskouing van die wese van die kerk, die volkskerkidee en Artikel III, hieronder weergegee sal word. Eers word aandag gegee aan die publikasies waarin Geyser implisiete kritiek uitgespreek het teenoor die Hervormde Kerk se verstaan van die volkskerkidee, en daarna kom sy publikasies aan die beurt waarin hy die Hervormde Kerk eksplisiet en direk gekritiseer het oor haar verstaan van die kerk as volkskerk, haar praktiese sendingbeleid, en daarby aansluitende handhawing van Artikel III.

\subsection{Indirekte kritiek op die volkskerkgedagte}

Volgens Van Aarde (1992b:160) lê Geyser se bydrae tot die verstaan van die Nuwe Testament in sy ondersoek na die universeel-gerigtheid van die vroeg-Christelike kerk wat met stryd sy partikulier-Joodse begrensing begin ontgroei het (kyk Geyser 1947/ 1948:86-95; 1953b:82-93; 1961/1962b:122-133). Die stryd in die vroeg-Christelike kerk tussen 'n partikulier-Joodse en 'n universeel-gerigte 'sendingbeleid' is volgens Geyser tydens die 'eerste Algemene Kerkvergadering', of Apostelkonvent (kyk Hand 15), op die spits gedryf (Geyser 1947/1948:130-131; 1953b91-93).

Hierdie vergadering het syns insiens op die oppervlakte oor twee sake gehandel: Of tafelgemeenskap tussen heiden-Christene en Christene uit die Jodedom toelaatbaar was, en of Christene uit die heidendom eers Joodse proseliete moes word, dit wil sê besny moes word, voordat hulle tot die volle Christelike gemeenskap toegelaat kon word (Geyser 1953b:91). Dieperliggend het die vergadering egter om veel meer gegaan:

Dit was inderdaad ook 'n dramatiese oomblik. Van die uitslag het die voortgang van die Christelike Kerk afgehang. Dit was die oomblik van beslissing of die Kerk hom sou vergenoeg om na binne te leef en of dit, trou aan die uitsendingsbevel van die Here, die groot awontuur sou onderneem om geheel-en-al na buite te leef; kortweg, of die Kerk bereid was om ondubbelsinnig sy apostolaat te onderneem.

(Geyser 1961/1962b:131)

Deur sy besluit het hierdie vergadering in gehoorsaamheid nie alleen die kerk bereid verklaar om ondubbelsinnig sy apostolaat te onderneem nie, maar ook 'die voortbestaan van die Christelike Kerk ... gewaarborg in sy leerbeginsel en samestelling' (Geyser 1953b:93; my beklemtoning). Die leerbeginsel was dat nie die wet van Moses nie, 
maar die geloof in Christus die voorwaarde vir die saligheid is. 'In sy samestelling, dat God's uitverkiesende genade die Jood en die nie-Jood gelyklik aansien' (Geyser 1953b:93). Volgens Geyser (1961/1962b:130) het hierdie vergadering dus vir eens en vir altyd die 'evangeliese beginsel van geen onderskeid tussen die gelowiges' vir die kerk vasgelê.

Vir Geyser was daar dus nooit enige twyfel oor die universele implikasies van die evangelie nie. Immers, reeds so vroeg as in 1947 - in 'n bydrae wat onder andere handel oor die verskille tussen die liturgie van die Joods-partikularistiese sinagoge en die universeelgerigte Christelike huissamekomste (Geyser 1947/1948: 86-95) — het dit vir Geyser duidelik geword dat die kerk nooit eksklusiwisties kon wees nie: Indien dit eksklusiwisme bo inklusiwisme verkies het, "kan ons met veiligheid verklaar dat die Christendom met die verwoesting van die Jerusalem en die nasionale Jodendom in 70 n.C .... ten einde sou geloop het' (Geyser 1953b:93).

Op grond van Geyser se verstaan van die Antiogeense teologie, soos dit in LukasHandelinge voorkom (vgl veral Hand 15), het dit vir hom duidelik geword dat die kerk, indien dit aan sy roeping wil beantwoord, 'bo nasionale en geografiese begrensinge [sal] moet uitstyg' (Geyser 1953:5). Die kerk moet dus poog 'om alger wat Christus bely as "God en Saligmaker" saam te bind' (Geyser 1953a:5). Die woord 'kerk' moet en kan daarom ook net in die enkelvoud verstaan en gebruik word (Geyser 1953a:5).

In 1948 spreek Geyser (1948:5) dan ook die standpunt uit dat daar van die kerk van Christus alleen gepraat kan word in terme van belydende kerk. As die kerk opgehou het om, as primêre opdrag, Christus met woord en daad te bely, beteken dit dat nog net die leë dop van die organisasie daar staan, 'nie langer as bolwerk van die geloof nie maar as voorwerp van liggelowigheid en bygelowigheid' (Geyser 1948:5). In die plek van Christus kom dan ' $n$ ander inhoud:

... 'n magspolitieke, 'n nasionaal-politieke ... of wat dan ook. Hoe nuttig so 'n 'Kerk' dan ook in die volksbelang, die politieke belang of selfs op internasionale gebied mag wees, dit vaar onder 'n valse vlag; dit het opgehou om Christus-kerk te wees en uit christelike oogpunt het ons niks meer daaroor of daaraan te sê nie.

(Geyser 1948:5)

Politieke, ekonomiese, kulturele en maatskaplike outoriteit is dus volgens Geyser (1948:5) nie lewensvoorwaarde of lewensfunksie van die kerk nie. Inteendeel. Dit is 'n versoeking en die oorsaak van die verwêreldliking van die kerk, indien die kerk dit 
begin nastreef. Indien die kerk op hierdie gebiede inbeweeg skakel hy hom gelyk met die wêreld, word hy ingesleep in die politieke gestoei, en word hy selfs mededinger op politieke, sosiale en ekonomiese gebied (Geyser 1948:5).

Alhoewel dit nie eksplisiet deur Geyser self gestel word nie, meen ek dat Geyser die Hervormde Kerk hier begin waarsku het betreffende Artikel III en die Hervormdè Kerk se selfverstaan as volkskerk. Dit is veral uit die volgende opmerkings van Geyser (1948:5) afleibaar: Om houvas te behou oor die Christelike volk het die kerk begin om die 'volkssentiment' aan te spreek, en om homself te populariseer het die kerk van homself as die 'Boere-kerk' begin praat. 'Dis wanhoopspogings en ons besef dit' (Geyser 1948:5; my beklemtoning). Of, soos Geyser dit self formuleer:

'n Boere-kerk met sy partypolitieke deelname, sy ekonomiese invloede, sy maatskaplike voortreflikheid, mag nasionale Kerk wees, maar hy het opgehou om Christus-kerk te wees. Hy mag 'n gedugte faktor wees in die staats- en wêreldmag, maar hy sal verleë staan in die verkondiging van die Evangelie van vrede en liefde. Hy sal sy roeping waarmee God hom geroep het, mis en hy sal in sy opdrag faal.

(Geyser 1948:5)

Geyser (1960/1961b:300-307) het bovermelde soort van indirekte kritiek op die Hervormde Kerk se handhawing van Artikel III voortgesit in, myns insiens, 'n briljante artikel getiteld 'Logos en ideologia: Woord en skynwoord' (Geyser 1960/ 1961b:300307). Die terme Logos en ideologia word deur Geyser soos volg gedefiniëer: Logos (d w s, die Woord van God), kom van God en manifesteer hom in die geskiedenis onder die mense. Dit heet waarheid en genade, word uitgedruk deur geloof en het 'n reddende krag. Ideologia, daarenteen, ontspring aan mense in die geskiedenis, het sy gesag van mense en manifesteer hom in praktyke van dwang. Dit het niks te doen met waarheid en genade nie, is mensgemaakte waarheid, word uitgedruk deur ongeloof en het vernietigende krag (Geyser 1960/1961b:303). Die Logos van God is verder liefde, en het onbeperkte en ongekwalifiseerde liefde gepredik, geleef en 'n volmaakte liefde gesterf en opgestaan. Ideologia, aan die ander kant, is in eie aanspraak ook 'n soort liefde, 'n liefde met beperkings en kwalifikasies, 'n liefde-vir-die-eie en 'n neutrale welwillenheid teenoor die nie-eie solank as laasgenoemde nie sy gesigsveld betree en die uitvoering van sy ideële programme beswaar nie. In wese is liefde-vir-die-eie dus niks anders as haat nie. Die liefde van die Logos, daarenteen, vra selfverloëning, die liefde-vir-die-eie egter beoog, leef, en vra selfbehoud. Die liefde-vir-die-eie neem in die geskiedenis altyd die gestalte aan van nasionalisme, en dan neig ideologia om eidololatria te word (Geyser 1960/1961b:306-307). 
Dit is duidelik wat Geyser (1960/1961b:300-307) met bogenoemde beeldspraak bedoel het: Die Logos is die Woord van God, die Woord wat eis dat die kerk universeelgerig die liefde sal verkondig, die vox Dei. Die ideologia is Artikel III, skynwoord, die vox populi: 'Die skynwoord, nieteenstaande sy aanspraak op gesag op Skriftuurlike grondslae, is nie Gods Woord nie, dit is maar mensewoord' (Geyser 1960/1961b:306). Geyser (1961/1962a:14-16) het later selfs sover gegaan as om te impliseer dat die kerk se gewete deur die handhawing van Artikel III toegeskroei is:

We have inverted conscience to ourselves. We have turned justice into self-righteousness, love into self-love, the duty to preserve life into selfpreservation, the respect for the dignity of the other man into self-respect.

(Geyser 1961/1962a:15)

Die simptoom van 'n siek mensheid (en dus by implikasie ook die Hervormde Kerk), is volgens Geyser (1961/1962a:14) die bereidwilligheid om die gewete te verruil vir wette (dus by implikasie, wette soos Artikel III). Die probleem is egter dat geen wet die gemeenskap (en kerk) kan bewaar of 'n lewendige gemeenskap kan maak nie. Die enigste geneesmiddel vir 'n siek gewete, syns insiens, was 'to remove ... the injustices, the oppression and the grievances which can cause the other man to become a menace to your own safety' (Geyser 1961/1962a:15). Dit wil sê, volgens Geyser die skrapping van Artikel III.

Die publikasie van A B du Preez (1959) se boekie, getitel 'Eiesoortige ontwikkeling tot volksdiens: Die hoop van Suid-Afrika', het aan Geyser 'n verdere geleentheid gebied om op 'n nie-direkte wyse krities op die Nederduitsch Hervormde Kerk van Afrika se verstaan van die volkskerkgedagte en handhawing van Artikel III te reageer. Hierdie werk van Du Preez het, myns insiens, die eerste keer aan Geyser (1960/1961a: 1-30) die geleentheid gebied om, in terme van ' $n$ 'neutrale' teologies-wetenskaplike debat - met Du Preez as gespreksvennoot - op 'n nie-direkte wyse krities op die Nederduitsch Hervormde Kerk van Afrika se verstaan van die volkskerkgedagte en handhawing van Artikel III te reageer ${ }^{4}$.

Volgens Geyser (1960/1961a:1) het die boek van Du Preez die doelstelling gehad 'om met Bybelse en ander argumente rasse-apartheid in alle moontlike betrekkinge, die Kerk inkluis, te propageer'. En al het Du Preez (1959:ii) ten doel gehad om 'deurgaans as Teoloog en Kerkman' te skryf, was Geyser (1960/1961a:1) van oordeel dat die werk 'n stuk 'ideologie'. was, te wete, 'die al-oue apartheid onder die nuwe naam, eiesoortige ontwikkeling' (Geyser 1960/1961a:1; sy kursivering). Juis daarom het Geyșer gevoel dat hy moes reageer, veral omdat 'die goeie naam van die Kerk en die wetenskaplike peil van die Teologie in Suid-Afrika' syns insiens op die spel was (Geyser 1960:61a:1). 
In die genoemde werk voer Du Preez (1959) hoofsaaklik die volgende argumente aan vir rasseskeiding op politieke sowel as kerklike gebied ${ }^{5}$ :

* Die Skrif leer dat die eerbiediging en normale ontwikkeling van die eiesoortige in die gemeenskap onontbeerlik is vir die Skriftuurlike leer van eenheid-in-verskeidenheid (Du Preez 1959:105). Die taalwonder op pinksterdag bevestig dit (Hand 2:8; kyk Du Preez 1959:68). Die werklike grond vir aparte kerke in SuidAfrika is daarom nie die sondige onwilligheid van mense om saam te aanbid nie, 'maar die feit dat verskillende volksgroepe elk na eie taal en kultuuraard moet bearbei word' (Du Preez 1959:254).

* Die laaste bevel van Jesus in Matteus 28:19a, asook Matteus 24:14, Openbaring 5:9, Openbaring 7:9 en Openbaring 19:15 veronderstel die voortbestaan van afsonderlike kerke (Du Preez 1959:68).

* Die Skrif leer wel die eenheid van die menslike geslag, maar slegs in soverre alle mense in Adam aangetas is deur die sonde en alle mense deur die tweede Adam, Christus, die verlossing ontvang (Du Preez 1959:64). Dit is duidelik uit onder andere Romeine 15:12c en 1 Korintiërs 15:21. Die Skrif leer dus dat die eenheid van die kerk eers 'n moontlikheid is na hierdie lewe, 'n 'geestelike eenheid' wat eendag, op die laaste dag, sal oorgaan tot 'n sigbare eenheid by die plene esse van die kerk (Du Preez 1959:136).

* Die beelde wat vir die kerk van Christus gebruik word, leer duidelik die verskeidenheid in die eenheid sowel as die feit dat dit moet bly voortbestaan (Du Preez 1959:101), soos dit duidelik blyk uit Romeine 14:4-5 en 1 Korintiërs 12:12$27^{6}$.

* Die Bybel eis nie van iemand om, indien hy 'n Christen wil wees, gedenasionaliseer te word nie (Du Preez 1959:106). Dit is duidelik uit 2 Korintiërs 4:5 en Handelinge 15:28-29.

* 1 Korintiërs 12:4-6 en Johannes 15 leer duidelik dat die wese van die eenheid van die kerk geleë is in gelowiges se gemeenskap met Christus, en nie in gemeenskap met mekaar nie. Die gemeenskap van gelowiges met Christus is dus meer fundamenteel vir die wese van die kerk as die kerk se uiterlike organisasie. Daarom is dit nie nodig om veclrassige eredienste, as 'n kunsmatige demonstrasie van die eenheid van die kerk, te hou nie (Du Preez 1959:108).

* Paulus wil die eenheid van die gemeente en nie die gelykheid (eendersheid) daarvan nie. Dit is veral duidelik uit Galasiërs 3:28 en Kolossense 3:11: As Paulus bedoel het dat daar in die kerk geen onderskeid gemaak moet word tussen Jode en 
Grieke, slawe en vrymanne en mans en vrouens nie en dat hulle 'n sigbare kerklike eenheid moet vorm, dan moet dit ook beteken dat man en vrou voortaan eenders sal wees, en dit is 'n feitlike onmoontlikheid (Du Preez 1959:67). Paulus vereis dus nie 'n sigbare eenheid van die kerk nie.

* Die eenheid van die kerk is alleen 'n eenheid in Christus, en hierdie eenheid vind alleen sy realisering in die eskatologiese, in die hiernamaals, in die onsigbare. Dit wil sê, die onsigbare eenheid van die kerk raak ons nie in ons sigbare bestaan nie. Verder: Die eenheid van die kerk bestaan volgens die Skrif daarin dat mense deur die gemeenskaplike geloof in Christus met mekaar verbind is as lede van dieselfde mistieke, geestelike liggaam. Die gelowiges wat in die kerk is, is broeders en susters, nie kragtens hulle gemeenskapsin, hul eensgesindheid, hulle broederlike liefde nie, maar kragtens die feit dat die een Christus vir Hom een kerk versamel het. Die eenheid van die kerk is dus geheel objektief gefundeer in Christus, en nie subjektief asof dit berus op die gesindheid of willekeur van mense nie. Allesn Christus verwerklik hierdie eenheid, soos dit duidelik blyk uit Johannes 10:17 (Du Preez 1959:107). Die sigbare eenheid van die kerk op aarde is wel 'n ideaal, maar ' $n$ ideaal wat nooit in die sigbare bereik kan word nie (Hand 6:1-7; 1 Kor 1:10-17; kyk Du Preez 1959:110).

* Rasseskeiding in die kerk is 'n opdrag van die Skrif omdat tekste soos Matteus 11:20-24, Matteus 23:15, 23, 25 en 27 en Openbaring 2 en 3 duidelik die kollektiewe verantwoordelikheid van rasse en volke leer (Du Preez 1959:102, 251).

Geyser (1960/1961a:3-15) reageer soos volg op bogenoemde argumente van Du Preez:

* Du Preez is korrek as hy beweer dat die Nuwe-Testamentiese bedeling nie die bestaan van aparte volke opgehef het nie, maar Handelinge 2:6-11 kan nie as bewys vir so 'n stelling aangevoer word nie. Op pinksterdag was daar nie sestien verskillende volke teenwoordig soos Du Preez beweer nie, maar net Jode (vgl Hand 2:5, $10 \mathrm{~b}, 22,36$ ). Verder sê Handelinge 2:39 dat God sy volk tot 'n eenheid sal versamel uit Jode en die wat daar ver is, die wat Hy tot Hom sal roep. In die Joodse idioom, meen Geyser (1960/1961a:4), beteken 'die wat daar ver is' die anderstalige, anderslykende en anderrassige heidene. Oor Handelinge 2:6-11 sê Geyser die volgende van die kerk:

Dit is dat God Kerk maak en dat God sy Kerk versamel. Kerk beteken uitgeroepenes, deur God geroepenes, van vér af, oor taal- en rasse- en nasionale-grense deur God nader geroepenes sodat die wat vér was en dis wat naby is, voortaan één, en sig- 
baar een sal wees soos Paulus dit ook stel in Ef. 2:11vv ... [A]s God saamroep ... het 'n kerklike groep ... nie die reg om op grond van kleur-, kultuur-, en taalverskil 'etniese' of enige soort kerke te 'stig' nie. 'n Kerk word nie 'gestig' deur eensoortige mense vir andersoortige mense nie. Die één, heilige algemene Christelike kerk is gemaak en word gemaak deur God. 'n 'Kerk' wat 'kerke' stig waag baie; hy is miskien nie bewus daarvan nie dat hy hom plaas in die plek van God.

(Geyser 1960/1961a:4-5)

* Die laaste bevel van Jesus in Matteus 28:19a veronderstel wel die voortbestaan van afsonderlike kerke (Geyser 1960/1961a:5). Maar Matteus 28:19b leer niks van die opdeling van die kerk in etniese, taal- of kultuurkerke nie. Jesus se sendingopdrag beteken juis die teenoorgestelde, naamlik dat die apostels dissipels moet maak, dit wil sê, lidmate van die één, algemene kerk, van mense uit al die nasies.

* Romeine 15:12c en 1 Korintiërs 15:21 handel volgens Geyser nie oor erfsonde en verlossing nie (Geyser 1960/1961a:6). Waaroor Romeine 15 egter wel handel, is dat Paulus die drie taal-, kultuur- en rassegroepe in die gemeente - bestaande uit Jode, Grieke en Romeine ${ }^{7}$ - tot eenheid oproep in weerwil van hulle verskeidenheid. En hierdie eenheid is nie 'n eskatologiese eenheid in 'n onsigbare kerk in 'n mistieke verbondenheid nie, maar histories en sigbaar (Geyser 1960/1961a:6).

* Romeine 14:4-5 en 1 Korintiërs 12:12-27 het, aldus Geyser (1960/1961a:6-7), niks te make met die beelde wat Christus vir die kerk gebruik nie, maar beide handel oor die verskeidenheid van ampte in dieselfde gemeente op grond van die verskillende genadegawes.

* Geyser (1960/1961a:7) stem saam met Du Preez dat die Bybel nie van iemand eis om, indien hy/sy 'n Christen wil wees, gedenasionaliseer te word nie. Dit is egter ook so dat die Bybel nie eis dat iemand 'tot 'n kleureensoortige, kultuureienaardige ras-eiesoortigheid genasionaliser moet word om Christen te word nie' (Geyser 1960/1961a:7). Wat Du Preez se verstaan van Handelinge 15:28-29 betref, reageer Geyser (1960/1961a:8) soos volg: Die 'Eerste Sinode' het so min agting vir die etniese yweraars gehad dat hy die voorstanders van so 'n etniese verdeling van die kerk in Antiogië skriftelik tereggewys en veroordeel het.

* Veelrassige eredienste is nie 'n kunsmatige demonstrasie van die eenheid van die kerk nie, maar die normale beoefening van die Christelike taak, die 'lof-offer aan God' wat nie 'n aannemer van persoon is nie (Geyser 1960/1961a:8). Verder, op 
grond van die getuienis van die Skrif is dit nie moontlik om te praat van 'n veelrassige gesamentlike erediens nie, 'want die Christelike Kerk is uit die hemel der hemele gegee en die veelheid van rasse is so aards as die aarde self. Die Kerk is nie veel- of enkelrassig nie, dis God's volk wat $\mathrm{Hy}$ uit die nasies of rasse tot 'n sigbare eenheid versamel het' (Geyser 1960/1961 a:8).

* Wat Galasiërs 3:28 en Kolossense 3:11 betref, meen Geyser (1960/1961a:9-10) dat Paulus nie die eendersheid van alle Christene bepleit nie, maar die eenheid van die kerk. Die eenheid van die kerk is verder nie alleen maar net 'n eskatologiese werklikheid nie. Die gemeentes aan wie Paulus geskryf het, was 'gemengde' gemeentes, histories 'nawysbaar' op aarde. Van hierdie gemeentes eis Paulus dat hulle, in weerwil van etniese, kulturele en sosiale onderskeide, een sal wees:

[E]k ... stel ... dat Kerk, volgens die Skrif, essensieël tot die historiese terrein behoort en dat wanneer die historie ophou, die Kerk oorgaan in die Koninkryk van die Hemele. In die hiernamaals is daar nie 'Kerk' nie, net Koninkryk .... Tweedens, die Kerk in die Nuwe Testament is die voortsetting van die Kerk van die Ou Testament ... daarom is die Christelike Kerk netso sigbaar as wat die volk van God in die Ou Testament sigbaar was en word van die Christelike Kerk netso 'n sigbare eenheid verwag as van die sigbare één Volk van God. Ten derde, die Nieutestamentiese woord vir Kerk is 'ekklesia' en dit beteken die vergadering van dié wat God uitroep uit die wêreld om vir Hom 'n volk te wees.

(Geyser 1960/1961a:10-11; sy kursivering)

Die eerste kern van die kerk wat Christus uit die wêreld uitgeroep het, was die dissipels, en vir hulle het hy gesê: Julle is in die wêreld en nie van die wêreld nie (vgl Joh 17:11, 14, 16). Dit beteken twee dinge vir die kerk (Geyser 1960/1961a: 11): Die kerk moet nie konformeer met die wêreld, met sy politieke, sosiale, etniese en kulturele indelinge nie, maar tog moet die kerk werklik en fisies in die wêreld teenwoordig wees. Die kerk is dus sigbaar en fisies in die wêreld teenwoordig - 'n sigbare eenheid - nie op grond van een of ander ideologiese eenheidstrewe of as kunsmatige demonstrasie nie, maar uit gehoorsaamheid aan die wil en Woord van God. So is die sigbare eenheid van die kerk die sigbare simbool van sowel die eenheid tussen Jesus en die Vader, as die eenheid tussen gelowiges en Christus en gelowiges onderling. Die eenheid van die kerk is dus nie alleen maar net ' $n$ eenheid in Christus as eskatologiese gebeure nie. 
* Geyser (1960/1961a:12-13) gee toe dat daar in die Bybel voorbeelde is van groepsbeoordeling. Maar dit is ook waar dat 'n sondige volk as volk geoordeel word as die individue waaruit daardie volk saamgestel is, soos een man aan God ongehoorsaarn is (vgl bv Jes 56:2; Jer 31:29-31).

\subsection{Direkte kritiek op die Nederduitsch Hervormde Kerk as volkskerk}

Waar Geyser in bovermelde geskrifte slegs indirek kritiek uitgespreek het op die Hervormde Kerk se selfverstaan as volkskerk en gepaardgaande handhawing van Artikel III, het Geyser vanaf 1960 op 'n direkte wyse die Hervormde Kerk begin kritiseer ten opsigte van Artikel III en die kerk. se sendingbeleid (Geyser 1960:12-23; 1961:5, 9, 16; 1960/1961a:1-30). Die rede hiervoor was waarskynlik tweeledig van aard, te wete, oplaaiende spanning in die teologiese fakulteit van die kerk (Pont 1990:11), en die komende Algemene Kerkvergadering van 1961 (Engelbrecht 1961:9).

Hoe dit ook al sy, in 1960 verskyn die veelbespreekte boek, getitel 'Vertraagde aksie: 'n Ekumeniese getuienis uit die Afrikaanssprekende kerk', waarin sowel Geyser (1960:12-23) as Van Selms (1960:36-47) 'n bydrae lewer. In 'n bydrae, getitel 'Die eerste evangelie oor die eenheid van die kerk as Christusgetuienis' huldig Geyser (1960:12-23) die volgende standpunte ten opsigte van die eenheid van die kerk:

Die vernaamste getuienis van die kerk lê nie in sy belydenis, prediking en gedragskode nie, 'maar in die feit dat dit Kerk is' (Geyser 1960:12). Vir die vroeë Christendom was die kerk 'so klaar en omlynd in sy andersheid' (Geyser 1960:12), dat die kerk na homself verwys het as 'n tertium genus, 'n derde menssoort, naas Romeine en Jode. Die kerk is daarom ' $n$ aparte volk, 'n sigbare volk, een volk tussen die nasies van die wêreld, oor die hele wêreld (Geyser 1960:12). Dat die kerk uit hierdie bewussyn gelewe het, blyk byvoorbeeld duidelik uit sy oudste geformuleerde belydenis, die Apostolicum.

Die artikel in die Apostolicum wat handel oor die wese van die kerk, lees volgens Geyser (1960:12-14) in die oorspronklike credo unam sanctam catholicam ecclesiam. Syns insiens moet die woordjie una in bogenoemde artikel nóg met ' $n$ ', nóg met 'een' vertaal word, maar eerder met 'ek glo die heilige algemene kerk':

Dit wil verklaar, nie alleen dat die Kerk een is nie, maar dat dit ook die enigste van sy soort is. Daar is nie Kerke ( $d$ w s volkskerke - EvE) naas die Kerk nie. In die eigenlike sin kan mens die woord 'Kerk' nie in die meervoud gebruik nie. Die Kerk wat die Christendom van die vroegste tye af bely, is een omdat dit die enigste Kerk is.

(Geyser 1960:13) 
Die daaropvolgende woorde van die artikel, 'heilige', 'algemene' en 'Kerk', asook die omskrywende bysin, 'die gemeenskap van die heiliges' beklemtoon elkeen op sy eie hierdie eenheid van die kerk:

* Die kerk is heilig, afgesonder vir God deur God, en omdat God een is, is die kerk ook enig en 'n eenheid;

* die kerk is algemeen, die hele wêreld omvattend, dus in die wêreld, en daarom moet die eenheid van die kerk 'n histories sigbare eenheid wees;

* die kerk is kerk as kuriakon, dit wil sê, dit wat aan die Here behoort. Daarom kan daar nie gepraat word van die Hollandse-, Afrikaanse, Boere- of Skotse kerk nie. Wat wêreldwyd die Here s'n is, kan nie opgedeel word om hier of op enige plek aan enige of al die nasies te behoort nie. Dit sê opnuut dat die kerk, te midde van die nasies en in weerwil van die nasies se geografiese, politieke en etniese verdeling, juis omdat dit aan die enige Here behoort, ondeelbaar een is; en

* die kerk is die gemeenskap van die heiliges, 'n gemeenskap wat met mekaar in doelbewuste persoonlike liefdevolle samesyn saamleef (Geyser 1960:13-14).

Die 'oorspronklike' woord vir kerk is ekklesia (Geyser 1960:14). In Matteus gebruik Jesus die woord ekklesia net twee keer, in Matteus 16:18 en Matteus 18:17. In Matteus 16:18 sê Jesus wat die kerk is, en in Matteus 18:17 sê hy wat die kerk nie is nie. In Matteus 16:18 is die 'rots' waarop die Here sy kerk bou, die skare van gelowiges (dus nie Petrus, die belydenis van Petrus of die Here self nie). Omdat die rots waarop die Here sy kerk bou die skare van gelowiges is (of dan die versamelde dissipels), is sy opdragte aan hierdie dissipels ook dit wat die kerk kerk maak (vgl Matt 10:1-4; 28:1820). Die kerk is daarom altyd sendende kerk, maar nie kerk en sendingkerk nie: Dit is ecclesia apostolata of niks (Geyser 1960:16) ${ }^{8}$.

Die Nuwe Testament gebruik verder verskeie beelde vir die kerk, soos byvoorbeeld dat die kerk die liggaam van Christus is (vgl 1 Kor 12:25-27; Rom 12:4, 5; Ef 1: 23; 2:16; 3:6; 4:4, 12, 16; 5:23, 28, 30; Kol 1:18; 3:15). Vanuit hierdie Skrifplase lei Geyser (1960:16-17) af dat daar 'n direkte verband is tussen die beeld van die kerk as liggaam van Christus en die nagmaal. Jesus het met die instelling nie alleen sy liggaam aan die kerk gegee nie, maar die kerk word so ook sy liggaam. Gelowiges wat dus saam aan die tafel van die Here sit, is die sigbaarste verskyningsvorm van die kerk.

Die opdrag van Jesus aan die kerk, die kerk as beeld van die liggaam van Christus, Jesus se instelling van die nagmaal en die sendingopdrag aan die kerk bepaal en bevestig dus die eenheid van die kerk - 'n sigbare eenheid - as wesenskenmerk van die kerk (Geyser 1960:17). 
Jesus se voorbidding vir die kerk in Johannes 17:9-26 spreek egter die duidelikste oor die onvoorwaardelike en sigbare eenheid van die kerk (Geyser 1960:17). In hierdie gebed verwys Jesus na die kerk as 'in die wêreld' (Joh 17:11, 18). Die kerk in die wêreld is dus duidelik histories sigbaar. Jesus bid ook vier keer dat hierdie kerk 'n eenheid mag wees (Joh 17:11, 21, 22, 23), 'n eenheid soos Hy en die Vader een is. Jesus verklaar in hierdie gebed ook wie hierdie eenheid moet wees ('die wat ... tot geloof in my sal kom; Joh 17:20 - NAV), en waarom hierdie kerk een - sigbaar een - moet wees ('sodat die wêreld kan glo dat U My gestuur het; Joh 17:21c - NAV).

Daarom is die eenheid van die Kerk, en met name sy in die historie sigbare eenheid, sy Christusgetuienis .... Die deel van die kerk wat hom dus op rasse- en kleurgronde verset teen die gebedsgebod van sy Here, doen 'n gevaarlike ding. Hy verontagsaam die eenheid van die Kerk en daarmee verstoor hy die Christusgetuienis van die Kerk. So 'n deel van die Kerk moet luister na die brief aan die gemeente in Efese. 'Anders kom Ek gou na jou toe en sal jou kandelaar van sy plek verwyder as jy jou nie bekeer nie' (Open. 2:5).

(Geyser 1960:18)

Om terug te keer tot Matteus 16:18: Volgens Geyser (1960:19-20) handel Matteus 16:18 oor drie baie belangrike eienskappe van die kerk:

* Alleen Jesus, en Hy uitsluitlik, bou kerk. Niemand anders doen dit nie. Hierdie feit verklaar die prinsipiële eenheid van die kerk. Die kerk kan homself dus nie verveelvoudig deur 'kerke' te stig nie, want nie die kerk stig kerk of kerke nie, maar Jesus alleen. "n Kerk of instelling of persone wat naas hierdie Kerk kerke, etniese, nasionale of kleurkerke stig, doen 'n gevaarlike ding: hulle eien hul die prerogatief van Christus toe. Hulle is liggaam wat maak of hulle Hoof is' (Geyser 1960:20).

* Die kerk is die eiendom van Christus. Dit is daarom 'n onding om van die kerk te praat as die besit van dié of daardie nasie.

* Die enigste troos vir die kerk is die feit dat die kerk nie aan die kerk self behoort nie, maar aan Christus. Die kerk is in sy weerloosheid en vervolgbaarheid dus die magtigste volk wat die wêreld ooit gesien het.

Laastens Geyser (1960:22) se verstaan van Matteus 18:15-17: Uit hierdie gedeelte lei Geyser af dat volharding in sonde die enigste rede kan wees hoekom iemand uit die kerk uitgesluit mag of kan word. Toelating tot die kerk, daarenteen, kan alleen plaasvind op grond van die Christusbelydenis, soos dié van Petrus (vgl Mark 8:29). Die kerk moet dus elke Christusbelyer op grond van sy/haar belydenis in die kerk opneem. 
As die kerk dan, in weerwil van hierdie belydenis, 'iemand wegwys, gaan die Kerk buite die grense van sy volmag en plaas hy hom in die plek van die soewereine Volmaggewer self' (Geyser 1960:22).

Bogenoemde was 'n duidelike, direkte aanval op die Hervormde Kerk. Net voor die Algemene Kerkvergadering van 1961 het Geyser egter ook polemiese debatte (lees persoonlike debatte) met sekere voorstanders van Artikel III in die Hevormde Kerk begin voer. In antwoord op sekere beskuldigings van Engelbrecht (1961:9), reageer Geyser (vir die laaste keer in Die Hervormer) soos volg9:

God sonder sy gelowiges van die ongelowiges af tot sigbare gemeenskap binne sy een kerk ongeag hulle liggaamlike verskille. Hierdie is egter nie 'n 'deurmekaarboerdery', 'bedgemeenskap' en 'ondertrouery', soos Engelbrecht (1961:9) beweer nie, maar die 'gemeenskap van die liggaam van Christus in die sigbare gemeenskap aan sy liggaam, dit is, tafelgemeenskap en Woordgemeenskap' (Geyser 1961:9).

Geyser (1961:9) stel dit verder dat hy (en Van Selms) beslis nie, soos Engelbrecht (1961:9) beweer, die geborgenheid in Christus stel teenoor die sigbaarheid van die kerk nie. Wat wel waar is, is dat 'die sigbare eenheid van die kerk wat in Christus is, die kerk se getuienis dat Hy die beloofde Christus van God is wat deur God in die sigbare wêreld gestuur is' (Geyser 1961:9).

Verder meen Geyser (1961:9) dat Engelbrecht (1961:9) hom verkeerderlik daarvan beskuldig dat hy Rooms is. Hy stel dit dat hy nog nooit die organisatoriese eenheid van die kerk gepredik het nie, juis omdat die eenheid van die kerk nie geleë is in sy uitwendige organisasie nie, maar 'in die onbelemmerde en vrye gemeenskap van die lidmate van die kerk nieteenstaande hul onderskeid van ras en klas' (Geyser 1961:9).

Geyser (1961:9) stel dit verder aan Engelbrecht dat hy ook steun vir sy standpunt vind in die werke van Augustinus (in sy De doctrina Christiana), Cyprianus (in sy De unitate ecclesiae) en Ignatius, asmede in die belydenis van Nicéa. Volgens Geyser bepleit hulle almal die sigbare eenheid van die kerk. Dieselfde geld ook vir Calvyn, soos dit blyk uit sy Confessio Gallicana, Artikels 25 en 26, en sy Institusie, Boek IV, 1, 2, 3 en 7: Ons is opgedra om hierdie sigbare kerk in ere te hou en ons in gemeenskap daarmee te hou, en dit wel op elke plek waar God 'n ware orde van sy kerk gevestig het.

Verder is die eenheid van die sigbare kerk nie iets anders as die eenheid van die onsigbare kerk, soos Engelbrecht (1961:9) beweer nie (Geyser 1961:9). Omdat die onsigbare kerk deur God vanuit die sigbare kerk uitgekies word, is die eenheid van die sigbare en onsigbare kerk dieselfde. Ook by Bucer (in sy werk Von der Wahren Seelsorge) vind Geyser $(1961: 9,16)$ ondersteuning vir sy standpunt. Volgens Bucer moet die kerk 'n versameling en die gemeente wees van hulle wat in onse Here Christus so 
deur sy Gees en Woord uit die wêreld versamel en verenig is, dat hulle een liggaam is en lede deurmekaar. Soos die Skrif pleit die vadere (en die ekumeniese belydenisse) dus vir eenheid deur gemeenskap (Geyser 1961:9, 16). Buitendien, die Skrif en die belydenisskrifte van die kerk leer in die eerste plek 'n sigbare kerk, en nie 'n onsigbare kerk nie (Geyser 1961:16) ${ }^{10}$.

\section{SAMEVATTING: GREYVENSTEIN EN GEYSER OOR DIE WESE VAN DIE KERK}

Greyvenstein se verstaan van die wese vản die kerk kan soos volg saamgevat word:

* Die kerk behoort aan die Hoof van die kerk, Jesus Christus - dit is sý gemeente;

* Jesus Christus self konstitueer sy kerk: die gemeente bestaan uit almal wat deur God gewederbaar is.

* Die gemeente omvat dus alle volke en geslagte, 'n kenmerk van die kerk/gemeente wat die kerk se grondslag vind in die eenheid van die menslike geslag, soos ons dit by Paulus vind (vgl Hand 17:26).

* Die gemeente moet in gemeenskap met God en die naaste lewe.

* Die wyse waarop die kerk as gemeenskap met mekaar moet saamlewe is dié van die liefde.

* Die enigste mag waarna die kerk mag streef, is die mag van die liefde.

* Die bloei van die kerk hang ten nouste saam met die gemeenskaplike liefdeskarakter van die kerk.

* Verloor die kerk die kerk se geestelike wese (liefde teenoor God en die naaste), hou die kerk op om kerk te wees.

* Klassevooroordeel en persoonlike/nasionale meerwaardigheid staan in teenstelling met die liefdeskarakter van die kerk.

* Die kerk mag nooit in die volk opgaan nie, maar moet die gewete van die wêreld en volk wees.

Bogenoemde lei tot die volgende logiese konsekwensie: Greyvenstein sou nooit positief kon staan teenoor die propagering van 'n volkskerkgedagte met eksklusiwistiese implikasies nie.

Geyser se verstaan van die wese van die kerk, wat insgelyks gesien kan word as sy kritiek op eksklusiewe volkskerke, kan by wyse van die volgende stellings saamgevat word:

* God maak en versamel sy kerk. Die kerk is die eiendom van Christus. Kerk beteken uitgeroepenes, deur God geroepenes, van vér af, oor taal-, rasse- en nasionale grense heen. Hierdie feit verklaar die prinsipiële eenheid van die kerk. 
Die kerk is ekklesia, die vergadering van dié wat God uitroep uit die wêreld om vir Hom 'n volk te wees. Die kerk is ook 'n tertium genus, 'n derde menssoort, naas Romeine en Jode. Die kerk is daarom 'n aparte volk, 'n sigbare volk, een volk tussen die nasies van die wêreld, oor die hele wêreld. Hierdie verstaan van die kerk kom veral tot uitdrukking in die Apostolicum: die kerk wat die Christendom van die vroegste tye af bely, is één omdat dit die enigste kerk is. Die enigste troos vir die kerk is daarom ook die feit dat die kerk nie aan die kerk self behoort nie, maar aan Christus.

* Die kerk moet sigbaar één wees, soos Paulus dit in al die gemeentes bepaal het.

* Die sigbare eenheid van die kerk is 'n opdrag van die Here (Matt 28:19-20), sodat die wêreld kan sien dat Jesus Christus die Verlosser is (Joh 17:21).

* Die woord 'kerk' kan nie in die meervoud gebruik word nie. Die kerk kan dus nie verveelvoudig word deur 'kerke' te stig nie. 'n Kerk word nie 'gestig' deur eensoortige mense vir andersoortige mense nie. Die één, heilige algemene Christelike kerk is gemaak en word gemaak deur God.

* Die sigbare eenheid van die kerk is nie bloot ' $n$ ideaal, 'n eskatologiese eenheid in 'n onsigbare kerk of 'n mistieke verbondenheid nie, maar histories in wese. Die kerk behoort tot die historiese terrein. Wanneer die historiese ophou, gaan die kerk oor in koninkryk. Die historiese van die sigbare kerk is verder daarin geleë dat die kerk in die Nuwe Testament ' $n$ voortsetting is van die kerk van die Ou Testament. Daarom is die Christelike kerk net so sigbaar as wat die volk van God in die Ou Testament sigbaar was, en word van die Christelike kerk net so 'n sigbare eenheid verwag as van die sigbare één volk van God in die Ou Testament. Die eis tot die sigbare eenheid vind dus nie sy grond in een of ander ideologiese eenheidstrewe of kunsmatige demonstrasie nie, maar in gehoorsaamheid aan die wil en Woord van God. Die sigbare eenheid van die kerk is verder die sigbare simbool van sowel die eenheid tussen Jesus en die Vader, as die eenheid tussen gelowiges en Christus en gelowiges onderling.

* Die sigbare eenheid van die kerk is nie geleë in sy uitwendige organisasie nie, maar in die onbelemmerde en vrye gemeenskap van die lidmate van die kerk nieteenstaande hulle onderskeid van ras en kleur.

* Die sigbaarste eenheid van die kerk word gevind in die saamwees aan die tafel van die Here.

* Toelating tot die kerk kan alleen plaasvind op grond van die Christusbelydenis. Indien die kerk enige ander vereiste (soos ras, taal of kleur) as toelatingsvereiste daarstel, verval die skeidslyn tussen die kerk en die wêreld, want dan konformeer die kerk met die wêreld met sy politieke, sosiale, etniese en kulturele indelinge. 
* Indien die vroeë kerk bogenoemde eksklusiwisme bo inklusiwisme verkies het, sou die Christendom met die verwoesting van Jerusalem en die nasionale Jodedom in $70 \mathrm{n} \mathrm{C}$ ten einde geloop het.

Soos in die geval van Greyvenstein, is eksklusiewe volkskerke dus vir Geyser 'n onmoontlikheid, omdat dit indruis teen die eise van die Skrif. Die een sigbare kerk waaraan almal behoort op grond van God se genade en die belydenis dat Jesus die Here is, is Woord. Eksklusiewe volkskerke daarenteen, is skynwoord, gebou op die ideologie van etniese meerwaardigheid.

\section{ENDNOTE}

${ }^{1}$ Hiermee word natuurlik nie ontken dat daar ook ander, meer positiewe, inhoude aan die volkskerkgedagte in die Nederduitsch Hervormde Kerk gegee word nie (vgl bv Van Wyk 1991:768782; Van Zyl 1989:86-98).

2 Die feit dat die debat in die Hervormde Kerk rondom die handhawing van Artikel III al dan nie eers in die begin van die sestigerjare werklik 'n debatspunt in die kerk geword het, blyk byvoorbeeld uit die volgende opmerking van Botha \& Pont (1993:17):

Oor lidmaatskap is daar byna so iets soos 'n dertigjarige oorlog in die Kerk gevoer. Vanaf 1961 wou die aanvallers op Artikel III deur die woord blank uit die Kerkwet te verwyder, poog om die band tussen die Kerk en die Afrikanervolk af te sny.

(Botha \& Pont 1993:17)

3 S P Engelbrecht (1960:7) en Ben Engelbrecht (1988:4) is van mening dat Geyser wel aanvanklik 'n ondersteuner van die Nederduitsch Hervormde Kerk se standpunt oor eksklusiewe lidmaatskap was, en die gepaardgaande sendingbeleid wat gerig is op die stigting van aparte volkskerke, maar later krities begin staan het teenoor sy vroeëre standpunt (vgl bv Geyser 1952:89-108; 1960:1223; 1961:5, 9, 16). Vir Van Aarde (1992b:166) is dit egter 'n vraag of daar wel so 'n ontwikkeling in die denke van Geyser aangetoon kan word, aangesien daar uit Geyser se publikasies sedert sy aanstelling in 1946 as professor in die Departement Nuwe-Testamentiese Wetenskap (Afd A) - afgelei kan word dat hy nooit twyfel gehad het oor die universele implikasies van die evangelie nie. Geyser (1961:16) self was van mening dat hy nie van standpunt verander het nie. Wanneer Engelbrecht (1961:9) hom beskuldig dat hy van standpunt verander het, sê hy dat hy vroeër geografiese segregasie in die oog gehad het, en nie 'n 'onbybelse segregasie tussen gelowiges van Christus in sy kerk nie' (Geyser 1961:16; vgl ook Geyser 1952:107). 
4 Dit is interessant dat die redaksie van die Hervormde Teologiese Studies, as voetnoot, die volgende op die titelblad van Geyser (1960/1961a:1) se artikel bygevoeg het: 'Die Redaksie verklaar dat die inhoud van hierdie artikel uiteraard vir [die] rekening van die outeur bly'. Dit, terwyl ook op die binneblad van die Hervormde Teologiese Studies (die blad waarop die inhoudsopgawe voorkom) 'n soortgelyke standpunt deur die redaksie uitgespreek is, te wete: 'Die Redaksie aanvaar uiteraard nie verantwoordelikheid vir die opinies van medewerkers nie'. Vir sover ek kon vasstel, is dit tot dusver die enigste keer in die bestaanstyd van die Hervormde Teologiese Studies dat dit gebeur het. Om hulle duidelike misnoeë met Geyser (1960/1961a:1-30) se standpunte in die genoemde artikel te kenne te gee, het die redaksie egter ook verder gegaan, deurdat net na Geyser (1960/1961 a:1-30) se artikel, 'n eie artikel deur die redaksie geplaas is, getitel 'Verklaring van die Nederduitsch Hervormde Kerk' (kyk HTS 16:31-32). Hierdie verklaring het duidelik die doel gehad om aan te toon dat Geyser se standpunt nié die van die Nederduitsch Hervormde Kerk verteenwoordig nie.

5 Slegs die argumente waarop Geyser (1960/1961a:1-30) gereageer het, word hier vermeld.

${ }^{6}$ Die wyse waarop du Preez (1959:105-106) hierdie twee tekste in verband bring met die verskillende beelde van die kerk in die Nuwe Testament, is nie duidelik nie.

${ }^{7}$ Uit die ou grafinskripsies in die katakombes in Rome blyk dit dat daar heel waarskynlik ook 'n hele aantal Noord-Afrikaners van onbepaalde kleur in die gemeente was (kyk ook Oetting 1964:25-51; Elliott 1988:42-71). In hierdie verband verwys Van Staden (1994b:1060) ook na Handelinge 13:1, waar 'Simeon wat ook Niger genoem is' as een van die profete en leraars van Antiogië genoem word. Bruce (1952:252), Newman \& Nida (1972:243-244) en Stählin 1975:173) meen dat hier beslis van 'n swart man sprake is. Persone is verder ook altyd geïfdentifiseer by wyse van etniese afkoms (bv Etiopiër), en nooit by wyse van ras nie. Laasgenoemde was skynbaar totaal onbelangrik (Van Staden 1994b:1060). In hierdie verband maak Barth (1951:245-349) ook die opmerking dat gegewenhede soos kultuur en kleur nooit ontken mag word nie, maar dat daar aan sodanige verskille nie teologiese status toegeken kan word nie.

${ }^{8}$ In hierdie verband word Geyser deur verskeie sistematiese teoloë soos Van Niftrik (1953:236), Ott (1981:426) en Schillebeeckx (1987:31) ondersteun (kyk ook Van Zyl 1976:92).

${ }^{9}$ Dit is eintlik ironies dat S P Engelbrecht, wat volgens Pont (1990:4) as ' $t$ ware daarvoor gesorg het dat Geyser as teologiese professor aangestel is, juis dié een is wat Geyser baie skerp oor sy verstaan van die volkskerkgedagte aangeval het (kyk Engelbrecht 1961:9). Hy het Geyser dan ook daarvan beskuldig dat hy sedert 1952 van standpunt verander het wat betref sy. verdediging van die Hervormde Kerk se sendingbeleid (kyk Geyser 1952:98-108). 
10 Sistematiese teoloë soos Küng (1971:263-276), Heyns (1978:379) en Weber (1983:552) gaan selfs verder as Geyser, deurdat hulle van mening is dat daar nie iets bestaan soos die 'onsigbare kerk' nie. Weber (1983:552) formuleer dit soos volg:

If it is true that the Church is the Community of Jesus Christ ... then it is not good to seek the unity ... of the Church as something essentially outside the Community which assembles locally .... The unity of the Church should be sought first of all within the Community and then in the co-operative of one Community with another.

(Weber 1983:552)

\section{Literatuurverwysings}

Bahr, G J 1970. The ceder of Passover and the eucharistic words. NT 12; 181202.

Barth, K 1951. Kirchliche Dogmatik, III. Zürich: Zollikon.

Beukes, C J 1994. Briewe van ons lesers: Hervormde teologie is 'n filosofiese teologie. Die Hervormer, 1 Maart 1994, bl 6.

Botha, S J (red) 1989. Belydende volkskerk. Pretoria: Kital.

Botha, S J \& Pont, A D 1993. Inleiding tot die nuwe Kerkorde, in Konsep Kerkorde en Ordinansies, 1-19. Nederduitsch Hervormde Kerk van Afrika.

Boshoff, P B 1990. Ons teologiese erfenis, Die Hervormer, 1 April 1990, bl 6.

- 1992. 'n Kenmerkend Hervormde teologie. Die Hervormer, 1 November 1992, bl 4.

- 1993. Spanning tussen die behoud van ons kerklike etos en aie Kerk se apostolaat. Die Hervormer, 1 Junie 1993, bl 5.

Breytenbach, A P B 1994. Hoe dink ons oor God? Die Hervormer, 15 Februarie 1994, bl 2.

Bruce, F F 1952. The acts of the apostles: The Greek text with introduction and commentary. London: Tyndale.

De Wet, J I \& Pont, A D (reds) 1964. Die vraekompleks rondom Artikel III van die Kerkwet. HTS 19/3, 103-137.

Dreyer, P S 1994. Teologie en filosofie. Die Hervormer, 15 Mei 1994, bl 5.

Dreyer, T F J 1994. Postmoderniteit - 'n opwindende risiko. Die Hervormer, 1 Maart 1994, bl 5.

Dreyer, W A 1995. Hier staan ek ... Frans van Zyl. Die Hervormer, 15 April 1995, bl 5, 8.

Du Preez, A B 1959. Eiesoortige ontwikkeling tot volksdiens: Die hoop van SuidAfrika. Pretoria: HAUM. 
Elliott, J H 1988. The fear of the leer: The evil eye from the Bible to Li'l Abner. Forum 4/4, 39-84.

Engelbrecht, B 1988. Professor A S (Albert) Geyser - 10 February 1918-13 June 1985. Journal of Theology for Southern Africa 64/3, 4-5.

Engelbrecht, S P 1961. Onaangename plig. Die Hervormer, Januarie 1961, bl 7.

Geyser, A S 1947/1948. Die dekaloog as bestanddeel van die vroeg-Christelike liturgie. HTS 4, 86-95.

- 1948. Die Kerk in die krisis, I. Die Hervormer, Augustus 1948, bl 5.

- 1951. Die kerk en die film, I. Die Hervormer, November 1951, bl 9.

- 1952. Kerklike lewe in Suid-Afrika. Kerk en Theologie 3, 98-108.

- 1953a. 'n Ekumeniese instituut in Utrecht. Die Hervormer Januarie 1953, bl 5.

- 1953b. Die 'eerste Algemene Kerkvergadering'. HTS 9/3 \& 4, 82-93.

- 1953c. Wyle prof H G Viljoen. HTS 9/3 \& 4, 82-93.

- 1960. Die eerste evangelie oor die eenheid van die kerk as Christusgetuienis, in Geyser, Marais, Du Plessis, Keet \& Van Selms 1960:12-23.

- 1960/1961a. Christelike godsdiens en eiesoortige volksdiens: 'n Beoordeling van die boek van prof dr A B du Preez, Eiesoortige ontwikkeling tot volksdiens. HAUM, Pretoria , 1959. HTS 16, 1-30

- 1960/1961b. Logos en ideologia: Woord en skynwoord. HTS 16, 300-307.

- 1961. Die Skrif beveel 'n sigbare eenheid van die kerk. Die Hervormer, Maart 1961, bl 5, 9, 16.

- 1961/1962a. Human dignity and conscience. Ministry 2/4, 14-16.

- 1961/1962b. Barnabas: Van Leviet tot apostel. HTS 17/2-4, 122-133.

Geyser, A S, Marais, B J, Du Plessis, H, Keet, B B, Van Selms, A et al 1960. Vertraagde aksie: 'n Ekumeniese getuienis uit die Afrikaanssprekende kerk. Pretoria: NG Kèrkboekhandel.

Greyvenstein, J H J A 1916. 'Zijt wakende, en versterkt het overige, dat sterven zou.' Open. 3:2. De Hervormer Julie 1916, bl 1-3. (Jrg 8, No 1.)

- 1917. Wij zijn Gods medearbeiders. 1 Kor. 3:9a. De Hervormer Augustus 1917, bl 1-3. (Jrg 9 nr 2.)

- 1920. In memoriam: Ds Goddefroy. De Hervormer 15 September 1920, bl vivii. (Jr $12 \mathrm{nr} 3$.

- 1928. 'Loof die Heere, mijne ziel' (Ps 103). De Hervormer Augustus 1928, bl 1. (Jrg $20 \mathrm{nr} 3$.

- 1933. Rede gehou deur prof dr J H Greyvenstein by die inwyding van die nuwe kerkgebou te Heidelberg. Die Hervormer, April 1933, bl 6-7. (Jrg 24 nr 2.) 
Greyvenstein, J H J A 1936. Oordenking: 'En Ik zeg u ook, dat gij zijt Petrus, en op deze petra zal Ik Mijne gemeente bouwen en de poorten der helle zullen haar niet oorwel-digen' (Matth 16:18). Die Hervormer, Januarie 1936, bl 6-9. (Jrg $26 \mathrm{nr} 11$.

- 1938. Eeufees-oordenking: 'Ek dink aan die dade van die Here; Ja ek wil dink aan U wonders uit die voortyd' (Ps 77 vs 12). De Hervormer 30 November 1938, bl 4-5. (Jr $29 \mathrm{nr} 15$.

- 1943/1944. Uit die gedagtewêreld van Paulus. HTS 1/1, 3-9.

Greyvenstein, J H, Engelbrecht, S P \& Gemser, B 1927. De gewetenklausule. De Hervormer Februarie 1927, bl 174-177. (Jrg $18 \mathrm{nr} 15$.

Hartin, P J 1988. Apartheid and the Scriptures: The contribution of Albert Geyser in this polemic. Journal of Theology for Southern Africa 64/3, 20-33.

Heyneke, F 1963. Korrespondensie: Dr A S Geyser preek in Nederlandssprekende Gemeente. Die Hervormer, Desember 1963, bl 24. (Jr 54 nr 9.).

Heyns, J A 1978. Dogmatiek. Pretoria: NGK Boekhandel.

Hindley, W R T 1993. Ortodoksisme: 'n Gevaar vir ons Kerk? Die Hervormer, 1 Julie 1993, bl 5, 7.

Jansen, C A 1993. Briewe van ons lesers: Die Woord van God is die antwoord. Die Hervormer, 1 Augustus 1993, bl 6.

Koekemoer, J H 1993. Teologie wil lidmate nie verwar. Die Hervormer, 1 September 1993, bl 3, 7 .

Küng, H 1971. The church. 6th edition. London: Search Press.

Loader, J 1993. Briewe van ons lesers: Dit het met verdagmaking en die integriteit van my opponent niks te make nie. Die Hervormer, 15 Julie 1993, bl 6.

Naude, J P 1960. Korrespondensie: Prof A S Geyser propageer veelrassige gehore vir ons eredienste. Die Hervormer, Augustus 1960, bl 18. (Jr $51 \mathrm{nr} 5$.)

Newman, B M \& Nida, E A 1972. A translator's handbook on the Acts of the Apostles. London: United Bible Societies.

Oberholzer, J P 1993. Die teologiese eie-aardigheid van die Nederduitsch Hervormde Kerk: Vrae en nuanses. HTS 49/4, 870-886.

Oetting, W 1964. The church of the catacombs: An introduction to the surging life of the early church from the apostles to A.D. 250 based on firsthand accounts. Missouri: Concordia Publishing House. (Church in History Series.)

Ott, H 1981. Die Antwort des Glaubens: Systematische Theologie in 50 Artikeln. Berlin: Kreuz Verlag.

Pont, A D 1990. Ongepubliseerde herinneringe. KITAL-biblioteek, Nederduitsch Hervormde Kerk van Afrika. 
Pont, A D 1994a. Oor 'n teologie vir die derde millenium. Die Hervormer, 1 Mei 1994 , bl 5,8 .

- 1994b. Kerk en belydenis. Die Hervormer, 1 Oktober 1994, bl 5.

- 1994c. Kerk en belydenis (2). Die Hervormer, 15 Oktober 1994, bl 5.

Schillebeeckx, E 1987. Jesus in our Western culture: Mysticism, ethics and politics. London: SCM.

Stählin, G 1975. Die Apostelgeschichte. Göttingen: Vandenhoeck. (NTD 5.)

Van Aarde, A G 1992a. Die eerste tree op weg na 'n kritiese en historiese NuweTestamentiese Wetenskap aan die Universitieit van Pretoria: Die bydrae van $\mathrm{J} \mathrm{H}$ J A Greyvenstein, hoogleraar 1917-1945. HTS 48/1 \& 2, 139-158.

- 1992b. A S Geyser, teologiese dosent 1946-1961. HTS 48/1 \& 2, 159-182.

- 1993a. Teologie vir die kerkvolk. Die Hervormer, 15 Augustus 1993, bl 5-6.

- 1993b. Moderniteit en postmoderniteit: Westerse samelewing by kruispunt. Die Hervormer, 1 Desember 1993, bl 5, 7.

- 1993c. Versoenende verskeidenheid, Die Hervormer, 15 September 1993, bl 5.

- 1993d. Mites, metafore en teologie (1), Die Hervormer, 15 Desember 1993, bl $5,8$.

- 1994a. Mites metafore en teologie (2), Die Hervormer, 15 Januarie 1994, bl 56.

- 1994b. Teologie vir die derde millenium. Die Hervormer, 1 Februarie 1994, bl 5,8 .

- 1994c. Die Ned Hervormde Kerk op pad na die 21ste eeu. Die Hervormer, 15 Februarie 1994, bl 5, 8.

Van Biljon, J 1993. Briewe van ons lesers: Prof Loader doelbewus in 'n swak lig gestel. Die Hervormer, 15 Julie 1993, bl 6.

Van der Merwe, P J 1993. Briewe van ons lesers: Liewer ortodoks as onortodoks. Die Hervormer, 15 Augustus 1993, bl 6.

Van Eck, E 1993. Galilee and Jerusalem in Mark's story of Jesus: A narratological and social scientific interpretation. DD-proefskrif, Universiteit van Pretoria.

Van Niftrik, G C 1953. Kleine dogmatiek. Nijkerk: Callenbach.

Van Selms, A 1960. Die gemeenskap van die heiliges en die kleurvraagstuk, in Geyser, Marais, Du Plessis, Keet \& Van Selms 1960:36-47.

Van Staden, P 1991. Compassion - the essence of life: A social-scientific study of the religious symbolic universe reflected in the ideology/theology of Luke. Pretoria: University of Pretoria. (HTS Suppl 4.)

- 1994a. Mag 'slegs blankes!' hier aanbid? HTS 50/3, 713-729. 
Van Staden, P 1994b. Woordverkondiging: 'n Universeelgerigte aksie. HTS 50/4, 1041-1069.

Van Wyk, D J C 1991. Kerk en volk. HTS 47/3, 768-782.

- 1993a. Redaksioneel: Ortodoksisme en modernisme. Die Hervormer, 1 Julie 1993, bl 4.

- 1993b. Redaksioneel: Die Hervormer, en sy opdrag. Die Hervormer, 15 Julie 1993, bl 4.

- 1993c. Redaksioneel: Dwingende maar interessante teologiese debat en onderskeidings lê voor. Die Hervormer, 15 Augustus 1993, bl 4.

- 1993d. Redaksioneel: Kerk en teologie. Die Hervormer, 1 September 1993, bl 4.

- 1994a. Redaksioneel: Kerk en teologie: Gesprek moet wyer en dieper. Die Hervormer, 15 Januarie 1994, bl 4.

- 1994b. Redaksioneel: Krities ook ten opsigte van die nuwe. Die Hervormer, 1 Maart 1994, bl 4.

- 1994c. Redaksioneel: Verskuiwings in ons teologie. Die Hervormer, 15 Mei 1994, bl 4.

Van Wyk, G M J 1994a. Oor die grens(e) tussen teologie en filosofie. Die Hervormer, 1 April 1994, bl 5.

- 1994b. Briewe van ons lesers: In die postmoderne tyd moet die teologie 'n filosofiese teologie wees. Die Hervormer, 1 April 1994, bl 6.

Van Wyk, I W C 1994. Nog steeds geslote eredienste? Deel 1. HTS 50/3, 755779.

Van Zyl, F J 1976. Die stem van die kerk in die wêreld. HTS 32/1 \& 2, 85-96.

- 1989. Volkskerk en vrye kerk, in Botha 1989:86-98. Pretoria: Kital.

Venter, P J J 1917/1918/1919/1919-1920 s a. Ongepubliseerde diktaatlesings van prof dr J H J A Greijvenstein, Faculteit van Godgeleerdheid aan die TUK gedurende die periode 1917-1920. Van Selms-leeskamer, Fakulteit Teologe (Adf A), Universiteit van Pretoria.

Verklaring deur die Nederduitsch Hervormde Kerk. HTS 16, 31-32.

Weber, O 1983. Foundations of dogmatics, Vol II. Grand Rapids: Eerdmans.

Wolmarans, J L P 1993. Briewe van ons lesers: U polemiek met prof Loader. Die Hervormer, 15 Julie 1993, bl 6. 